\title{
Management control and privatization in the United Kingdom
}

\author{
Michael Ian Cragg* \\ and
}

I.J. Alexander Dyck**

We examine the links between ownership and internal control for a sample of 112 state-owned, privatized, and publicly traded firms in the United Kingdom from 1970 to 1994. Privatized firms with at least four years in the private sector, like established publicly traded firms, exhibit a significant negative relationship between improved performance and the probability of resignation. Simulations using model estimates show a one-standard-deviation decrease in performance raises the probability of resignation by $90 \%$ in publicly traded firms and by $180 \%$ in established privatized firms. Stateowned firms and privatized firms in their first four years show no relationship between the probability of resignation and changes in financial performance.

\section{Introduction}

- Margaret Thatcher's selloff of state-owned firms from the United Kingdom catalyzed a global wave of privatization. Operating in more competitive product markets, privatized firms' output, profits, and share prices have predominantly increased, whereas prices facing consumers have usually not grown. ${ }^{1}$ What is less clear is how privatization has enhanced efficiency.

To paraphrase John Hicks (1935), this article investigates whether privatization works by disturbing "the best of all profits" of state ownership, a quiet life. One characterization of the owner-manager relationship under state ownership is that managers are effectively treated like bureaucrats and are rarely fired, and firing is unrelated

* Analysis Group/Economics; mcragg@ag-inc.com.

** Harvard University; adyck@ hbs.edu.

We thank Jasper Hoek, John McGuire, and James Schorr for diligent and able research assistance and the contributions of many former and current executives at U.K. firms, government officials, and representatives of regulatory agencies. The article benefited greatly from comments by Jim Hosek, Glenn Hubbard, Julio Rotemberg, Debora Spar, two anonymous referees, Editor Robert Porter, and various seminar participants. The research would not have been possible without the financial support of the Division of Research of Harvard Business School. All errors that remain are our own.

${ }^{1}$ Empirical evidence includes Galal et al.'s (1994) detailed investigation of twelve privatizations in three countries, Megginson, Nash, and van Randenborgh's (1994) international investigation of firms privatized through IPOs, and empirical investigations of specific countries such as LaPorta and Lopez-de-Silanes's (1997) investigation of Mexican firms. 
to changes in a firm's financial performance. Consequently, managers have little incentive to focus on financial performance. From this perspective, privatization can improve performance if new private owners make the probability of a manager's retaining his position contingent on financial performance. Recognition of the link between financial performance and firing will raise management incentives and perhaps management turnover.

To examine the links between ownership and internal control, we investigate the level of management resignation and the sensitivity of management resignation to changes in firm financial performance for state-owned, privatized, and publicly traded firms in the United Kingdom. We exploit a unique panel dataset of 112 large U.K. firms from 1970 to 1994, which includes information from 40 state-owned and 39 privatized firms. The dataset includes reliable information on management resignation, various firm performance measures, manager-specific attributes, industry-specific attributes, and controls for time trends.

The United Kingdom is an excellent testing ground to evaluate possible links between the identity of the owner and the relationship between owners and managers. ${ }^{2}$ As in many countries now considering privatization, state-owned enterprises in the United Kingdom have played a very important role in the post-World War II economy. By 1979, when Margaret Thatcher became prime minister, nationalized industries accounted for almost one-tenth of gross domestic product in the United Kingdom and one-seventh of investment. The privatization program has also been comprehensive, introducing more than forty of the largest state-owned firms into the private sector between 1980 and 1991. The significant number of firms and variation in the timing of privatizations facilitate an empirical comparison of control mechanisms under different ownership structures.

As in most countries experimenting with privatization, U.K. firms have also, on average, delivered a consistently higher level of financial performance following privatization than under state ownership. Figure 1, using data from our sample (described in more detail below), suggests a significant relationship between financial performance and ownership. Relative to a benchmark sample of publicly traded firms owned by private individuals, state-owned firms consistently deliver a much lower rate of return on net operating assets. But privatized firms, these same firms that exhibited poor financial performance under state ownership, consistently deliver returns fluctuating around the average level of publicly traded firms. The change in financial performance associated with privatization is seen more clearly when we organize data around the privatization event, as in Figure 2. ${ }^{3}$ This change in financial performance prompts an inquiry into what has changed with privatization.

This article complements recent empirical studies on privatization. These studies document changes in actions and performance of firms following privatization (e.g., Megginson, Nash, and van Randenborgh, 1994, and LaPorta and Lopez-de-Silanes, 1997). An older literature documents cross-sectional differences across private and state-owned firms (see Boardman and Vining (1989) for a meta-analysis of research in this area). Most of these studies focus on inputs, such as employment or investment policies, or on output measures including financial performance and efficiency measures. We focus on the change in incentives and management human capital, some of the higher-level changes in these organizations.

\footnotetext{
${ }^{2}$ For more extensive discussions of the privatization program, see HM Treasury (1995), Vickers and Yarrow (1988), Bishop and Kay (1988), and Yarrow (1989).

${ }^{3}$ Galal et al.'s (1994) detailed investigation of three privatized U.K. firms shows that these increases in producer surplus do not come at the cost of consumers' or workers' surplus. Prices have been kept in check by new regulatory agencies that have also monitored and ensured product quality.

() RAND 1999
} 
FIGURE 1

MEAN AFTER-TAX RETURN ON NET OPERATING ASSETS

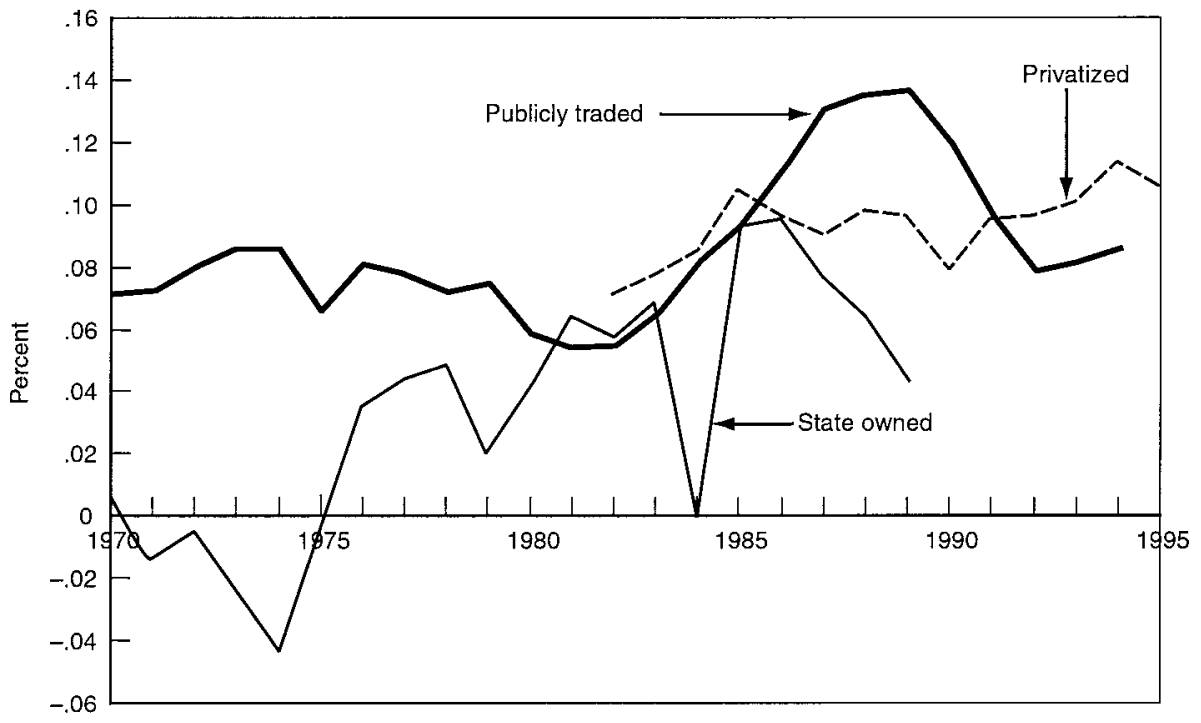

Source: Datastream International and company annual reports. Sample includes data from 112 firms.

FIGURE 2

MEAN AFTER-TAX RETURN ON NET OPERATING ASSETS RELATIVE TO PRIVATIZATION YEAR

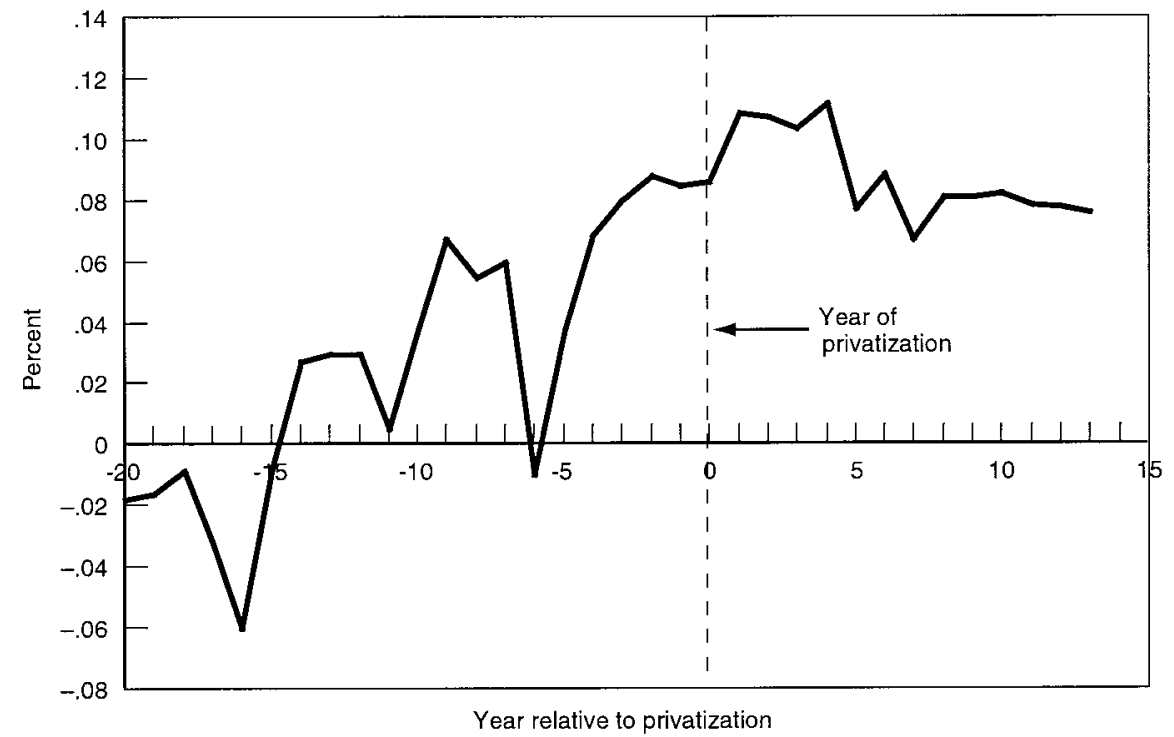

Source: Company annual reports. 
The focus on the managerial labor market follows earlier work in the United States by De Alessi (1974) that showed more secure tenure in state-owned than privately owned U.S. electric utilities. In the privatization context, management human capital and incentives have received far more theoretical interest than empirical evaluation. ${ }^{4}$ Notable exceptions include studies of significant changes in management provided by analysis of transition economies (Barberis et al., 1996, and Dyck, 1997) and developing economies (Lopez-de-Silanes, 1997), although the applicability of these findings to privatization more generally is unclear.

Resolution of the debate about whether privatization affects internal control systems and how these changes are introduced is interesting for a number of reasons. The sensitivity of management replacement to changes in financial performance provides a test for the relationship between ownership and incentives. The management turnover estimates relate to the argument advanced in the transition economies that the replacement of management human capital, independent of any change in incentives, is an important component of the privatization process. Finally, the evidence can contribute to the debate about design of privatization programs and the desirability of restrictions on privatized firms. Reports of dramatic increases in managerial compensation and no reports of increases in accountability in privatized firms have had a significant political effect in the United Kingdom. Political concerns threaten both the freedom of action granted to newly privatized firms and efforts to expand the privatization program.

The welfare conclusions from this analysis must nonetheless remain tentative. Evidence of changes in the owner-manager relationship is necessary but not sufficient for privatization to improve performance by enhancing incentives. It is beyond the scope of this article to evaluate how the extent of management change and the sensitivity of management replacement to firm performance directly influence efficiency.

The article proceeds as follows. In Section 2 we provide some context for our empirical analysis by presenting theoretical arguments about the relationship between ownership and incentives. Section 3 describes some institutional features of the ownermanager relationship in the United Kingdom that casts some doubt on the stronger theoretical predictions. In Section 4 we present our main analysis and describe the data and empirical results. Section 5 provides testimony from the documentary record and management interviews to facilitate interpretation of the empirical findings. Section 6 concludes.

\section{Theoretical issues}

- From a theoretical perspective, it is not immediately obvious why private owners would be more effective than public owners at resolving agency problems arising from the separation of ownership and control. The agency relationship between owners and managers in large state-owned firms and large publicly traded firms is more alike than different. In privatized firms, ownership change may not transform managers into owners in any meaningful way. Like state owners before, new shareholders are faced with the difficult challenge of establishing monitoring and incentive mechanisms to encourage managers to utilize their unique knowledge of the business situation, given differences in objectives. Most mechanisms available to private owners to reduce agency costs and align the interests of owners and managers are also available to state owners. Consequently, privatization may not change this relationship.

${ }^{4}$ Theoretical approaches to privatization and incentives include Sappington and Stiglitz (1987), Shapiro and Willig (1995), and Laffont and Tirole (1991). Wolfram's (1998) investigation of personnel changes and compensation for executives in U.K. electric supply companies is one of the few empirical examinations in developed countries.

() RAND 1999 
But almost all theoretical agency models that attempt to incorporate ownership generate a link between ownership and incentives. We focus on two theoretical approaches: one based on changes in owners' objectives and another based upon changes in owners' monitoring intensity.

Ownership might affect incentives by the objectives conveyed to managers by owners. Shareholders in private firms expect managers to pursue maximization of shareholder value. In contrast, ministers responsible for state-owned firms are partially interested in how decisions affect societal welfare. Political theories remind us that politicians may also sacrifice the economic well-being of state-owned firms to pursue private goals such as reelection and personal financial benefits. ${ }^{5}$ In the Shapiro and Willig (1995) model, managers of state-owned firms are given an objective that weights private and social welfare. These objective-based theories suggest that privatization insulates management from political and social goals. Hence, new private owners are more likely to focus on financial objectives and to redirect incentives to enhance financial performance.

Property rights theories, articulated by Alchian (1977), Demsetz (1988), and others, suggest an alternative explanation. In their view, the shareholder is the residual claimant to profits in publicly traded firms, whereas under state ownership, property rights are ill defined. Although the state is the residual claimant to any profits in a state-owned firm, the minister (as the state's representative) has no financial interest in the returns stemming from his actions (or inaction). Moreover, there is unlikely to be a personal gain to the minister. Among the activities in the minister's portfolio of responsibilities, monitoring state-owned enterprises is likely to be relatively invisible to the electorate. So long as there is no personal gain and some personal cost in designing or managing an effective governance system, state representatives will neither work hard at monitoring managers nor design governance systems to enhance efficiency. To exacerbate this problem, managers of state-owned enterprises are insulated from the threat of takeover and bankruptcy common to privately owned firms.

Property rights theories predict that privatization will enhance incentives tied to firm financial performance by replacing disinterested ministers with shareholders who will design an effective governance system out of self-interest. To the degree that privatization limits effective corporate governance, such theories predict fewer incentives in privatized firms relative to established publicly traded firms not subject to these constraints. In particular, the corporate governance literature suggests that the strength of incentives will depend on how privatization affects ownership concentration, the ease of transfer of ownership, and the level of financial freedom granted to management, among other factors. ${ }^{6}$

\section{Institutional background}

- Institutional features of the owner manager-relationship in the United Kingdom temper the stronger theoretical predictions about the effect of privatization. In this section we highlight three important features of the owner-manager relationship: formal similarities in the structure of governance relationships, restrictions placed on corporate control in newly privatized firms, and reported weaknesses in established publicly traded firms.

${ }^{5}$ Boycko, Shleifer, and Vishny (1996) focus on the agency problems that lead managers to maximize private benefits rather than financial performance.

${ }^{6}$ Shleifer and Vishny (1997) survey this literature.

() RAND 1999 
Unlike some other countries, in the United Kingdom there was no formal difference in the relationship between owners and top executives for state-owned and publicly traded firms. Reflecting a desire for an "arm's-length" approach, most state-owned firms had since their inception been incorporated as public corporations separate from their sponsor ministries. As in established publicly traded firms, formal control rights in state-owned firms were delegated to a board of directors, and top management were treated neither as employees nor as civil servants. While the sponsor minister had powers beyond those of the board, intervention by other political actors was limited. For example, parliamentary questions about day-to-day management were not allowed, and the comptroller and auditor general of the ministry were not permitted to scrutinize the firms' accounts. Thus, for many firms, privatization did not lead to the creation of new oversight groups but rather led to minor changes in the identity of some nonexecutive board members. ${ }^{7}$

In addition, privatized firms were sheltered from some mechanisms that might contribute to effective governance in publicly traded firms. In most privatizations, the U.K. government relied on initial public offerings and reserved significant portions of share issues for the general public. This policy limited initial share concentration and made corporate governance more difficult. ${ }^{8}$ The government also reduced the possibility of takeovers that might discipline incumbent management by including a "special share" in most enterprises. The special share required any suitor interested in acquiring more than $15 \%$ of a firm to seek government approval. Finally, the government often restructured the balance sheets of firms in advance of privatization, lowering debt levels and making bankruptcy and/or bank oversight less likely.

Bishop and Kay (1988), in a comment on the privatization of British Gas, argue that "[t]here is little caricature in describing this privatization as a deal between ministries and an industry chairman (each unenthusiastic about the proposal) in which the latter accepted privatization in return for an assurance that it would not really make any difference" (p. 88).

It was also unclear whether the control systems of established publicly traded firms were working effectively. By the 1990s, two influential commissions reported significant weaknesses. The Cadbury report characterized boards in publicly traded firms as instruments of the chairmen, since executive directors voted in line with their chairman, nonexecutive directors typically made up a minority on the board, and nonexecutives rarely determined executive compensation. ${ }^{9}$ The Greenbury report focused more directly on weaknesses in the design of compensation plans. It noted the lack of performance-related pay, a limited emphasis on long-run performance measures, and excessive executive control of compensation setting. Empirical studies such as Gregg, Machin, and Szymanksi (1993) confirm the weaknesses in governance highlighted by these reports.

\section{Empirical analysis}

- Ultimately, the nature of the relationship between owners and managers is an empirical question. To examine this question we sought to assemble a dataset that

${ }^{7}$ Behind this structural similarity were some significant differences. As Heath (1976) notes, in stateowned firms, ministers and statutes constrained management discretion, having the power to appoint all directors and approve borrowings, investment project, and distribution of surpluses. Statutory restrictions to give only general directions to the board and management were often ignored.

${ }^{8}$ Incentives built into the privatization program discouraged individuals from selling their shares. For example, customers of privatized water utilities were eligible for either a free share for every ten shares held more than three years, or a discount on future installment payments for their shares. Noncustomers were eligible for one free share for every 20 shares held more than three years.

${ }^{9}$ Percy (1994) summarizes the Cadbury report and its recommendations.

(C) RAND 1999 
included management and firm performance information for all the state-owned U.K. firms that were privatized or were candidates for privatization. We began with a list of state-owned firms in 1975 and identified all medium to large firms that provided commercial goods or services, focusing on firms organized as public corporations. From this target group we excluded any firms that became a disparate collection of small firms at the time of privatization and included any new state-owned firms created after 1975. This left 41 state-owned firms and 42 privatized firms. We were able to assemble data for 40 of the 41 targeted state-owned firms and 39 of the 42 targeted privatized firms. ${ }^{10}$ Where possible we assembled complete data on management and firm performance for 1970 through 1994. Our sample, therefore, includes almost all of the 48 major privatized firms identified by the Department of the Treasury in 1995. It provides a comprehensive picture of owner-manager relationships in U.K. state-owned and privatized firms.

We also assembled comparable data for a set of firms that remained publicly traded throughout the time period. For 32 state-owned firms in 1975 we assembled a list of all publicly traded firms with the same Financial Times classification code available from Datastream. ${ }^{11}$ We reduced this list by requiring all firms to have assets at least as great as the second-largest government-owned firm in the overall sample. We picked randomly from the remaining firms and retained the firm if copies of annual reports were available in the archives of Harvard University's Baker Library. If reports were not available, we randomly drew another firm. For state-owned firms without comparisons, we used the sample of firms in Datastream with the Financial Times equivalent of the same one-digit SIC code and chose firms with sales levels within $20 \%$ of the target firm. The Appendix describes our data-collection approach and presents descriptive statistics.

Top management resignation. A first step is to examine the extent of top management replacement and see if it is linked to the type of owner. We identified top management using two definitions of top decision makers in each firm. Following Weisbach (1988) and others, we identify "top executives" as anyone with the title "executive chairman" or "chief executive officer." 12 Since these two titles do not always correspond with an individual's real decision-making power, our second definition follows Warner, Watts, and Wruck (1988) and Denis and Denis (1995) by allowing more individuals to be part of the "top management" team. Our definition of top management includes all individuals with the title "executive chairman," "executive deputy chairman," "chief executive officer," or "managing director."

We focus on management resignations. Resignation here describes events when a manager ceases to be employed by a firm. Theoretically, the wage the board is willing to offer is less than the wage the manager is willing to accept.

We also present information based on our classification of resignations as voluntary and involuntary. Voluntary resignations are commonly called quits, and involuntary resignations are commonly called fires. This classification captures qualitatively different events. For example, for many fires the board is unwilling to offer any wage to a

\footnotetext{
${ }^{10}$ New state-owned firms created since 1975 and added to our database are British National Oil Company, British Aerospace, and Nuclear Electric. Firms excluded because they were broken into many small parts include National Bus, British Ship Builders, and the Rover Group.

${ }^{11}$ Datastream employs the FTSE Actuaries Industry Classification system. The one-digit classification identifies broad business categories, the two-digit classification identifies particular sectors, and the threedigit classification gives more detailed subsectors (www.ft-se.co.uk).

${ }^{12}$ We use shareholding, options, and compensation information to identify the chairman's executive status where it is not clear from the published accounts.
}

() RAND 1999 
manager, whereas for many quits the board makes few material changes to its wage offer. Involuntary resignations might provide a stronger indicator of incentives, as they are initiated by an agent (the board) outside of the managers' control and managers perceive that they can affect the probability of firing through their actions. This classification also has its weaknesses. In addition to the theoretical similarity between voluntary and involuntary resignations, it is difficult to disentangle them empirically. On balance, the additional information provided by classifying resignations as voluntary and involuntary is a useful complement to resignation information alone, if interpreted cautiously.

To classify resignations as involuntary (fires) or voluntary (quits), we used information on reported reasons for departure and age information. Our principal sources were company annual reports, press reports about the resignation and new appointments in The Financial Times, and other publications available on-line using Lexis-Nexis (post-1981); because press reports were not available on-line before 1981, we also used biographical information in Who's Who (pre-1981).

Our confidence in our classification of individual resignations differs greatly across observations. Some reported reasons for departure were straightforward enough to allow us to classify resignations with little doubt. We defined a resignation as a voluntary departure where the reported reason was death or health concerns, or when the manager clearly took an equal or greater position in a similar firm. We defined a resignation as a disciplinary turnover when the press report said that the manager was fired, when the departure resulted from board conflict, or when the manager took another position at a lower level or in a much smaller firm.

Other reported causes of resignation provided less information. In particular, the most often stated reasons for departure were that the manager "retired" or "took no new position." Both of these reported reasons could indicate a voluntary departure or could be a euphemism for a firing. For such unclear resignations we relied more heavily upon age information to identify quits and fires. Increased age raises a manager's probability of quitting, as an older manager will be eligible for pension payments and most likely has a higher valuation of leisure time or lower valuation of wage income. We classified these resignations as quits if the manager had reached typical retirement age (65) and as disciplinary turnover otherwise. Our principal results presented below are robust to alternative empirical models of executive turnover, including sequential choice models with full and partial observability. ${ }^{13}$

Resignation, firing, and ownership. The raw data suggest that ownership influences top management resignations and involuntary turnovers. Table 1 presents results relating ownership and time to the level and extent of resignation activity based on 3,081 executive-year observations. The annual rate of resignation activity is $16.1 \%$ in privatized firms, $14.3 \%$ in state-owned firms, and $12.6 \%$ in established publicly traded firms. The difference in turnover levels between privatized and publicly traded firms is significant ( $p$-value .03), while the difference between state-owned and privatized firms is insignificant ( $p$-value .18). ${ }^{14}$

The distinctive nature of owner-manager relationships in privatized firms is clearer when we classify resignations as quits and fires. Figure 3 depicts a consistently higher level of fire activity for top managers in privatized firms. Panels B and C of Table 1 report the percentage of all turnovers attributable to clear quits and fires and those

${ }^{13}$ These results are presented in an earlier version of this article, Cragg and Dyck (1998a).

${ }^{14}$ These turnover rates are similar to those found in studies for the United States (9.3\%), Germany (10.9\%), and Japan (12.9\%) by Denis and Denis (1995), Kaplan (1994), and Kang and Shivdasani (1995) respectively.

(1) RAND 1999. 


\begin{tabular}{|c|c|c|c|c|}
\hline & Privatized & State Owned & $\begin{array}{c}\text { Publicly } \\
\text { Traded }\end{array}$ & All Firms \\
\hline \multicolumn{5}{|l|}{ Panel A: Observed Turnover Probability } \\
\hline Annual top management turnover (percent) & 16.1 & 14.3 & 12.6 & 13.8 \\
\hline Number of turnovers in sample & 73 & 173 & 183 & 429 \\
\hline Annual top executive turnover (percent) & 15.4 & 14.3 & 11.8 & 13.2 \\
\hline Number of firms & 40 & 39 & 33 & 112 \\
\hline \multicolumn{5}{|l|}{ Panel B: Reasons for Turnover, 1970-1979 } \\
\hline Annual top management turnover (percent) & - & 15.1 & 13.0 & 14.0 \\
\hline As a percent of total turnover in category & - & & & \\
\hline Clear quits & - & 28.1 & 13.2 & 20.9 \\
\hline Unclear quits & - & 7.3 & 29.0 & 17.7 \\
\hline Clear fires & - & 11.0 & 13.2 & 12.0 \\
\hline Unclear fires & - & 53.7 & 44.7 & 49.4 \\
\hline \multicolumn{5}{|l|}{ Panel C: Reasons for Turnover, 1980-1995 } \\
\hline Annual top management turnover (percent) & 16.1 & 13.9 & 12.3 & 13.7 \\
\hline \multicolumn{5}{|l|}{ As a percent of total turnover in category } \\
\hline Clear quits & 5.5 & 28.6 & 9.4 & 14.8 \\
\hline Unclear quits & 6.9 & 9.9 & 15.1 & 11.1 \\
\hline Clear fires & 41.1 & 14.3 & 19.8 & 23.7 \\
\hline Unclear fires & 46.6 & 47.3 & 55.7 & 50.4 \\
\hline
\end{tabular}

Note: The sample has 3,081 executive-year observations.

attributable to unclear quits and unclear fires for each ownership category. Resignations are more likely in privatized firms, and more of those resignations can be classified as possible fires. The fire rate in privatized firms is significantly higher than in publicly traded and state-owned firms ( $p$-values of .00). There is no statistically significant

FIGURE 3

TOP MANAGEMENT FIRE RATES, 1970-1995

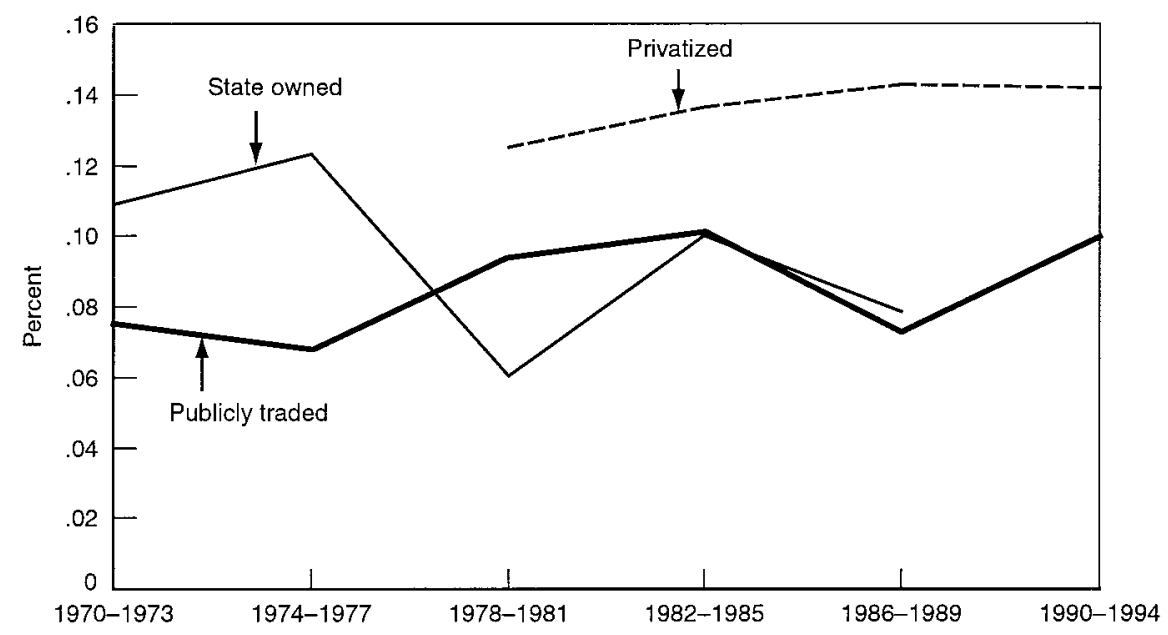

() RAND 1999 
difference between the fire rates of state-owned and publicly traded firms ( $p$-value .66). The relatively high number of quits in state-owned firms is partially accounted for by the policy of circulating top management from smaller to larger state-owned firms or from lower to higher positions in firms within the same industry.

This evidence on raw turnover levels, however, does not reveal a quiet life in stateowned firms in comparison to their publicly traded counterparts. Consistent with the findings of Geddes (1997), who focuses on electric utilities, we find no statistically significant difference in turnover probabilities between government-owned and investor-owned firms. This contrasts with De Alessi's (1974) finding of a lower probability of turnover in state-owned firms.

We also account for the time relative to privatization. There could be peculiar features of the years surrounding privatization. In our regression setting, we divide state-owned firms into those for which there has been an announced intention to privatize and those without such an announcement. ${ }^{15}$ In our sample, the time between announcement and privatization varied from one to eight years, with a mean of three years. For privatized firms, we divide the sample into the first four years and time after the first four years. This allows for different patterns in the first few years as a privatized firm, when the firm is likely to be restructured, possibly by new management. For a number of the firms in our sample, this period also corresponds to the time before the government's "golden share" expired.

Figure 4 depicts how time relative to privatization influences top management turnover. The privatization period appears to be unusual. There is a lower level of turnover in the privatization year and in the three years preceding privatization (the average period between announcement and privatization). Turnover increases significantly following privatization. There appears to be little difference in the rate of management resignation or firing in privatized firms in the transition period of the first four years or more than four years later.

These data indicate that privatization does affect the owner-manager relationship. The significantly higher level of firing and the higher likelihood of management turnover both immediately after privatization and as privatized firms gain more experience suggest that market forces affect how firms operate. Human capital replacement appears to be an element of the privatization process. Moreover, the high level of replacement is still evident more than four years after privatization. This evidence clearly conflicts with skeptics' predictions of no changes following privatization.

Sensitivity of resignation to changes in financial performance. Raw turnover levels are insufficient to evaluate the incentives facing managers. An important sense of the "quiet life" is whether managers are held to account for firm performance. Using regression analysis, we examine whether resignations and fires were more likely under poor financial performance across our different firm types. We define the performance variables, describe our statistical methodology, and then present our empirical results.

We examine the change in accounting earnings as our primary indicator of firm performance using the change in the return on assets (ROA). By focusing on the change in financial performance, we control partially for differences in the level of financial performance across industries. Our goal was to find an accounting measure that reflects owners' interests and is available for all our firms for the whole sample period. We define ROA as the ratio of operating income after depreciation, interest, and taxes to

${ }^{15}$ To identify the year of privatization announcement, we consulted a number of sources, including company annual reports, Fraser and Wilson (1988), and Barbe et al. (1986).

() RAND 1999. 
FIGURE 4

TOP MANAGEMENT TURNOVER RELATIVE TO PRIVATIZATION YEAR

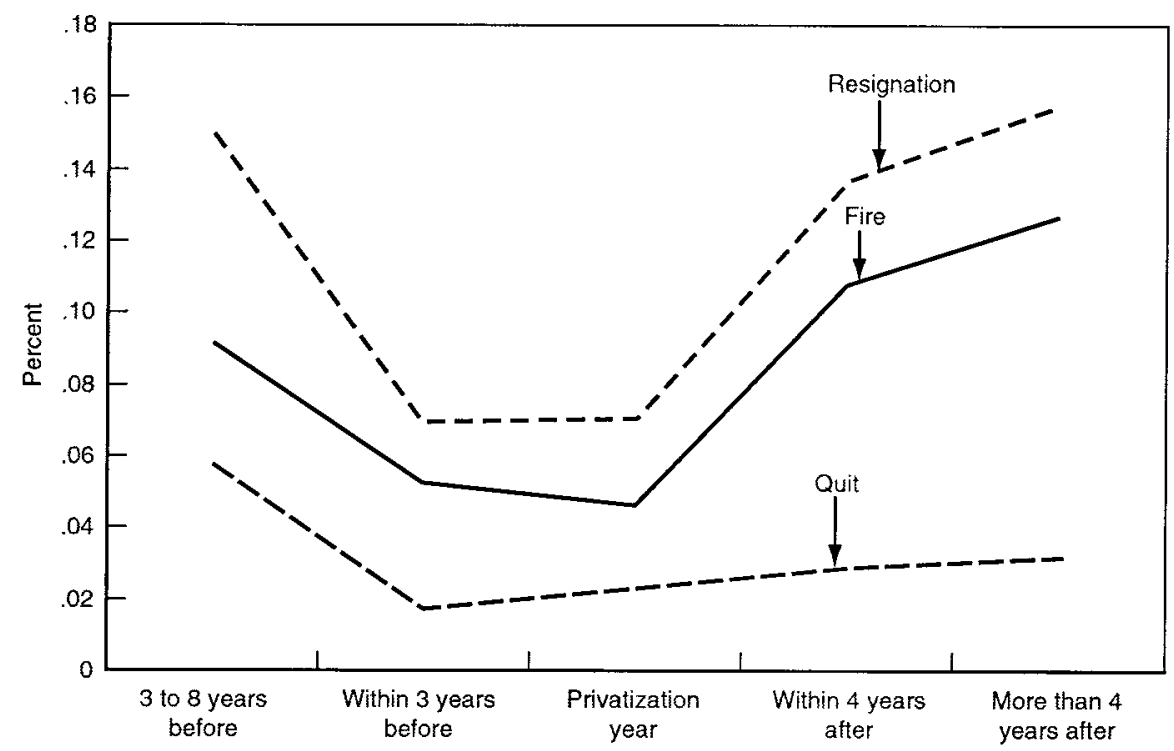

net operating assets (total assets less current liabilities). Operating income after interest and taxes is highly correlated with cash flow, which is of significant interest to owners. ${ }^{16}$ We use net operating assets rather than total assets because for many state-owned firms there is no reported measure of current liabilities. Our results, presented below, are robust to alternative measures such as ROA using operating income before interest and taxes, and return on sales (Cragg and Dyck, 1998a).

Although accounting earnings have well-known weaknesses, they also have advantages. They are available for all firms in our sample, they constitute a measure of short-run profitability, and they are related, albeit imperfectly, to the firm's long-run profitability. There is evidence (Cosh, 1975) that boards of directors use accounting earnings in determining bonuses, and one would expect to see the same relationship with dismissals. ${ }^{17}$

Accounting measures also provide information in state-owned firms. State-owned firms were organized as public corporations with annual financial accounts audited by the same private accounting firms that audit as publicly traded firms. Throughout the postwar period, the government used financial targets as an important indicator of firm performance. As made clear in the 1961, 1967, and 1978 White Papers, the most commonly used financial targets have consisted of a rate of return on assets. Of course, unlike firms in the private sector, state-owned firms have other targets including social objectives and, since the control system reform following the 1978 White Paper, performance aims and external financing limits. Because the government made efforts to quantify and provide grants to cover the cost of some noncommercial objectives, changes in financial performance provide some evidence of management efforts.

${ }^{16}$ Unfortunately, annual reports did not consistently report depreciation expenses for all of the firms in our sample.

${ }^{17}$ The use of accounting earnings follows examinations of managerial turnover in the United States by Denis and Denis (1995), and in Germany and Japan by Kaplan (1994). 
Our empirical approach combines information on management resignation with performance information. Specifically, we allow the probability of resignation for each manager $i$ at time $t$ to be a function of the change in financial performance of the manager's firm, ownership type, manager-specific attributes (age, tenure), time relative to privatization, time, and industry-specific attributes. We differentiate changes in firm and industry performance by ownership type. We first employ a logit specification with two states, either to stay with the firm or to resign. Second, we use our classification of resignations as fires and quits. To account for the three possible states a manager could occupy in any year-fire, quit, or remain - we employ a multinomial logit specification. Our regression analysis focuses on top executives rather than top management to avoid a potential bias due to a correlation between turnovers among top managers in the same firm that is hard to capture in our empirical specification. ${ }^{18}$

Resignation sensitivity. We find both ownership and time relative to privatization have a significant impact on the relationship between changes in financial performance and the probability that a manager stays. This pattern of results is equivalent using resignation (Table 2) or quits and fires (Table 3) as our dependent variable. ${ }^{19}$ The estimated effects are stronger for quits and fires. ${ }^{20}$

The statistically significant negative sign on after-tax returns for publicly traded firms indicates that top executives are likely to resign when the firm's rate of return on assets declined. Top executives are also more likely to resign if they are employed by privatized firms in the private sector for more than four years that had a bad year. The coefficients on privatized and publicly traded are not statistically distinguishable ( $p$-value of .31 (Table 2), .20 (Table 3)). In stark contrast, for state-owned firms before the announcement of an intention to privatize, we cannot reject the hypothesis that there is no relationship between after-tax returns and resignations. The coefficients differ significantly between state-owned and publicly traded ( $p$-value of .02 (Table 2), .01 (Table 3)) and between state-owned and privatized ( $p$-value of .04 (Table 2), .02 (Table 3$)$ ). The effects differ in the period immediately surrounding the privatization event. For state-owned firms between announcement and privatization, and for privatized firms in the first four years, we cannot reject the hypothesis that there is no relationship between changes in after-tax returns and the probability of turnover. The estimated coefficients are not statistically distinguishable ( $p$-value of .26 (Table 2), .18 (Table 3))..$^{21}$

Simulations using the predicted coefficients facilitate a comparison of the differences in the use of management resignation as a disciplinary device. To illustrate the sensitivity of resignation to changes in firm performance, we use a 5\% change in ROA, a magnitude less than one standard deviation for our full sample (6\%). For state-owned firms there is little relationship between resignation and changes in firm performance. A deterioration of ROA of 5\% from average firm performance actually lowers the probability of resigning (being fired) from $16 \%(12 \%)$ to $15 \%(11 \%)$. In contrast, in

${ }^{18}$ To address concerns about possible serial correlation arising from the rare instance of having two top executive observations for a firm in a year, we also investigated a series of regressions in which we included only a single executive from each firm. Our results were robust to these specifications.

${ }^{19} \mathrm{We}$ are not able to reject the hypothesis of comparable levels of resignation and firing for top executives across our ownership types.

${ }^{20}$ However, we are not able to reject the hypothesis that quits are equivalent to fires, in terms of having identical coefficients on all of the performance interaction terms ( $p$-value of .62).

${ }^{21}$ Using a technique outlined by Chamberlain (1984), we control for fixed effects in our logistic estimator by conditioning on the number of managerial turnovers over the sample period, first in the company and second in the ownership type. We are able to reject the need to control for fixed effects at the .05 significance level.

(c) RAND 1999 
TABLE 2 Sensitivity of Resignation to Changes in Financial Performance

\begin{tabular}{lccc}
\hline & & Robust & \\
& Coefficient & Standard Error & $P>|z|$ \\
\hline Change in after-tax return on net operating assets & & & \\
$\quad$ State owned, no privatization announcement & & & .218 \\
State owned, announced privatization & 1.788 & 1.452 & .615 \\
Privatized, first four years & -4.517 & 8.980 & .273 \\
Privatized, after four years & 9.883 & 9.019 & .050 \\
Publicly traded & -25.331 & 12.902 & .032 \\
Firm type & -11.222 & 5.239 & .004 \\
State owned, no privatization announcement & & & .136 \\
State owned, announced privatization & 1.142 & .396 & .173 \\
Privatized, first four years & .871 & .585 & .102 \\
Privatized, after four years & .647 & .475 & .000 \\
Controls & .637 & .389 & .600 \\
Age & & & .000 \\
Age $\geq 65$ & .097 & .022 & .000 \\
Tenure & .147 & .281 & .000 \\
Tenure squared & .249 & .047 & .002 \\
Constant & -.009 & 1.407 & \\
Number of observations & -9.543 & 1486 & \\
Log-likelihood & & -504 & \\
Pseudo $R^{2}$ & & .11 & \\
\hline
\end{tabular}

Note: Logit regression with resignation as the dependent variable $(0=$ stay, $1=$ leave $)$. Regression uses Huber-White (robust) standard errors.

both publicly traded firms and privatized firms with at least four years in the private sector, the probability of resignation increases when firm performance deteriorates. For publicly traded firms, a deterioration of ROA of 5\% from average firm performance raises the probability of resigning (being fired) from $6 \%(5 \%)$ to $10 \%(9 \%)$. For firms four years after they were privatized, a change of the same magnitude raises the probability of resigning (being fired) from $10 \%$ (9\%) to $29 \%$ (33\%).

The time around the privatization event differs, although the lack of statistical significance suggests caution in interpreting these findings. For state-owned firms with an announced intention to privatize, turnover is more likely if firm performance deteriorates. More difficult to interpret is the positive relationship in privatized firms between performance change and resignations in their first four years in the private sector. Boards may be using performance metrics other than accounting earnings. Given the up-front costs associated with major restructuring efforts, other performance metrics like stock market returns might provide a less noisy indicator of future firm performance. A less benign interpretation is that corporate governance structures are weak initially and that managers are not held to account for financial performance. ${ }^{22}$

Time and resignation sensitivity. We are also interested in whether there have been significant time trends in the attention to corporate governance activity in the United

${ }^{22}$ Yet another interpretation is that this reflects a lack of accountability in firms subject to price regulation. For our dataset, many of the observations in the "first four years of privatization" category are accounted for by firms subject to price regulation. For a further discussion of this issue, see Cragg and Dyck (1998a).

(C) RAND 1999. 
TABLE 3 Sensitivity of Fires and Quits to Changes in Financial Performance

\begin{tabular}{|c|c|c|c|c|c|c|}
\hline & \multicolumn{3}{|c|}{ Fires } & \multicolumn{3}{|c|}{ Quits } \\
\hline & \multicolumn{3}{|c|}{ Standard } & \multicolumn{3}{|c|}{ Standard } \\
\hline & Coefficient & Error & $P>|z|$ & Coefficient & Error & $P>|z|$ \\
\hline \multicolumn{7}{|l|}{$\begin{array}{l}\text { Change in after-tax return on net operating } \\
\text { assets }\end{array}$} \\
\hline State owned, no privatization announcement & 1.332 & 2.339 & .569 & 2.056 & 1.910 & .282 \\
\hline State owned, announced privatization & -14.086 & 12.108 & .245 & 1.107 & 9.207 & .904 \\
\hline Privatized, first four years & 7.158 & 10.398 & .491 & 10.017 & 19.651 & .610 \\
\hline Privatized, after four years & -33.767 & 15.007 & .024 & -6.188 & 23.869 & .795 \\
\hline Publicly traded & -13.775 & 4.882 & .005 & -4.458 & 8.080 & .581 \\
\hline \multicolumn{7}{|l|}{ Firm type } \\
\hline State owned, no privatization announcement & .976 & .486 & .044 & 1.715 & .676 & .011 \\
\hline State owned, announced privatization & -.010 & .900 & .991 & 1.922 & .856 & .025 \\
\hline Privatized, first four years & .860 & .580 & .138 & .257 & .869 & .768 \\
\hline Privatized, after four years & .614 & .495 & .215 & .902 & .669 & .177 \\
\hline \multicolumn{7}{|l|}{ Controls } \\
\hline Age & .105 & .024 & .000 & .070 & .039 & .070 \\
\hline Age $\geq 65$ & -1.058 & .368 & .004 & 1.814 & .452 & .000 \\
\hline Tenure & .284 & .069 & .000 & .195 & .082 & .017 \\
\hline Tenure squared & -.011 & .003 & .002 & -.007 & .004 & .037 \\
\hline Constant & -10.356 & 1.481 & .000 & -9.752 & 2.33 & .000 \\
\hline Number of observations & \multicolumn{6}{|c|}{1486} \\
\hline Log-likelihood & \multicolumn{6}{|c|}{-596} \\
\hline Pseudo $R^{2}$ & \multicolumn{6}{|c|}{.13} \\
\hline
\end{tabular}

Note: Multinomial logit regression with "stay" as the omitted category.

Kingdom. The institutional record suggests increased attention to financial performance in state-owned enterprises in the 1980s following the introduction of a new control system, the election of the Thatcher government, and a general improvement in the finances of U.K. companies (discussed below). The record also suggests increased scrutiny of all publicly traded firms in the 1990s. To explore the possibility of time trends, we first interacted time dummies with our firm types and with our firm performance change variables. Figures 5 and 6 present the results from one such attempt where we included decade dummies.

Significant time trends would be indicated by an increase in the gap between predicted turnover probabilities for negative and positive performance changes, and perhaps by a switch from a positive to a negative relationship. There is some evidence in support of positive time trends. As shown in Figure 5, in publicly traded firms, the resignation sensitivity increases in each decade. However, this result is relatively weak, is not reflected in other ownership groups, and is not found when we identify resignations as fires and quits, as shown in Figure 6.

While these results suggest few trends in corporate governance activity, we nonetheless took further steps to see if there was such a relationship. Our claim to have identified an ownership effect would be more difficult to maintain if there had been a significant increase in attention to governance over time because state-owned firms are overrepresented in early years and privatized firms are overrepresented in later years. 
FIGURE 5

\section{PREDICTED TOP EXECUTIVE RESIGNATION PROBABILITY}

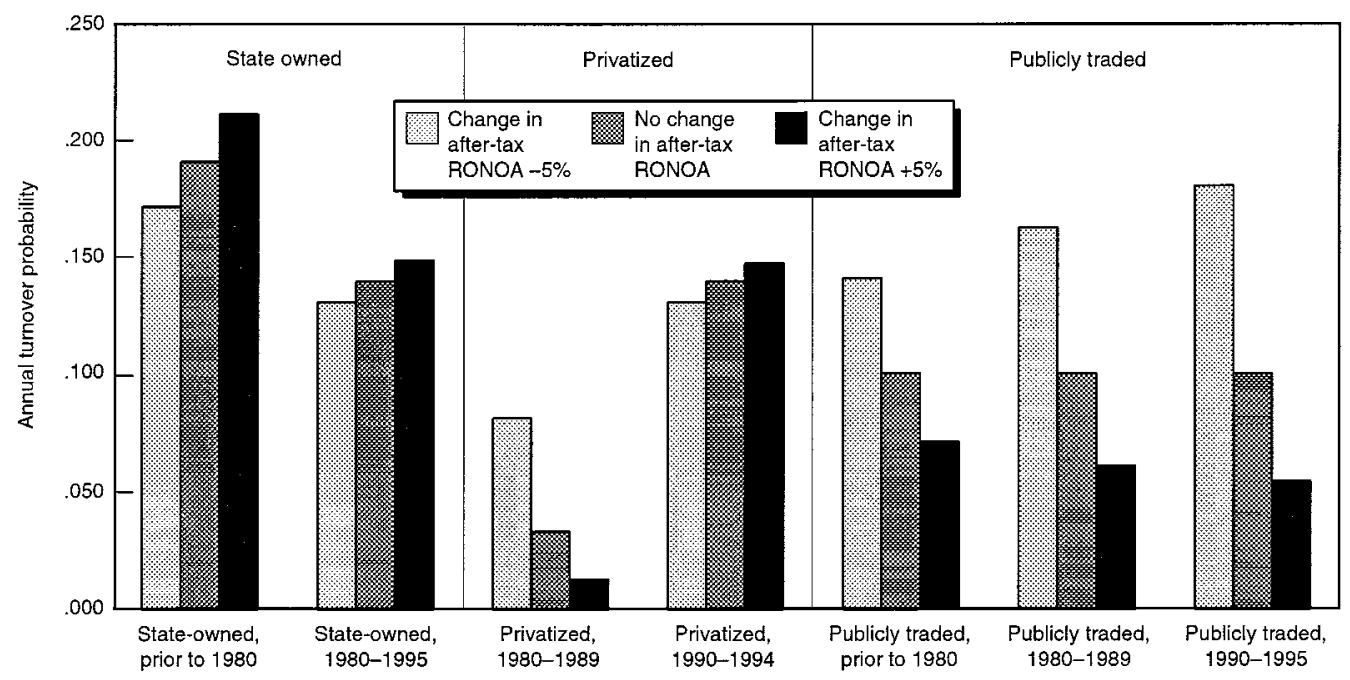

Note: The probabilities calculated using estimates from a regression (not presented) that includes firm type and management control variables. RONOA = return on net operating assets.

Under these circumstances, the observed differences could arise due to the ownership change, or they could have taken place just due to the patterns over time.

We investigate whether a time trend may have generated the apparent difference in accountability in state-owned and privatized firms by amending the regressions in

\section{FIGURE 6}

\section{PREDICTED TOP EXECUTIVE FIRE PROBABILITY}

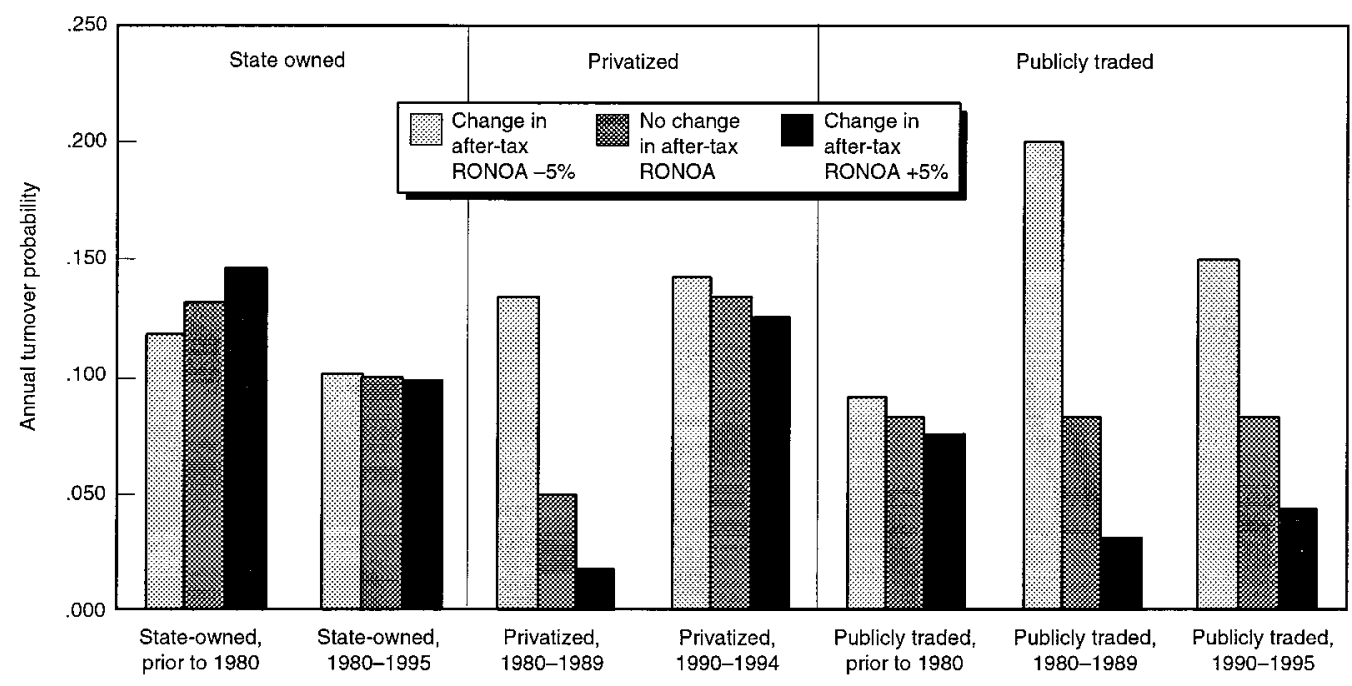

Note: The probabilities calculated using estimates from a regression (not presented) that includes firm type and management control variables. RONOA = return on net operating assets. 
Table 3. We allow for time trends in turnover and sensitivity to changes in after-tax returns for all firms over our sample period. Second, we performed the same tests after dropping the data prior to 1980. In all specifications (not presented), we found the same pattern of results as presented above, and we found that our time trend variables were not significant. Finally, we looked at results in just the 1990s. Again we found the same pattern of results. ${ }^{23}$ If a time trend were driving our results we would have expected to see a strong negative relationship both for new and for established privatized firms.

Other variables. In other regressions not presented we looked for evidence of relative performance comparisons. Theory suggests that boards of directors interested in rewarding or penalizing results attributable to management efforts should not penalize (reward) managers when industry performance deteriorates (improves), only when performance relative to the industry declines (improves). Empirically, this suggests that the sign on industry performance should be opposite to that on own-firm performance and significant. Incorporating the additional data (described in the Appendix) did not change our pattern of results and does not reveal significant use of relative performance comparisons (Cragg and Dyck, 1998a).

\section{Qualitative evidence}

- There are at least two possible interpretations for our finding of a significant sensitivity of resignation to changes in firm financial performance in established privatized firms and no such finding for state-owned firms. One is that there was less effort devoted to control activity under state ownership. An alternative interpretation is that there might have been just as much control activity under state ownership, with a focus on performance relative to other objectives.

To examine the alternative hypothesis that state-owned managers were maximizing other objectives, the alternative objectives need to be specified, and performance relative to these objectives needs to be measured. Such a classification is not available. But, sensitive to this possible interpretation, we gathered some additional data to see if this theoretical concern was important as a matter of practice. The documentary and interview data presented below, while decidedly imperfect, attempt to fill this void.

For background information on the period of state ownership, we consulted various official documents. ${ }^{24}$ For further insight, we directly asked senior executives how accountability systems had changed. We visited the United Kingdom in the spring of 1996 and again in the summer of 1997 and interviewed an average of two senior executives in 13 privatized firms, senior representatives from two regulatory agencies, a representative from the Treasury, and analysts of privatized industries in three major investment houses. The majority of the executives interviewed were either chairman or chief executive officer, with other executives sitting on the board or heads of divisions or functional areas. ${ }^{25}$ The evidence must remain suggestive, but in our view it reinforces the conclusions we have derived based on the empirical evidence and provides additional insight on how to interpret the evidence.

${ }^{23}$ The coefficient estimate for privatized firms with more than four years in the private sector remains highly negative but is less statistically significant because of the drop in sample size.

${ }^{24}$ We consulted Review Body on Top Salaries (1974, 1978, 1980, 1981), House of Commons Select Committee on Nationalised Industries (1968, 1979), National Economic Development Office (1976), HM Treasury White Papers on the Nationalised Industries (1961, 1967, 1978), and Vickers and Yarrow (1988).

${ }^{25}$ The interviewed executives had experience under state ownership and as new hires since privatization. The privatized firms included firms from the electric generation, water and sewage, and electric distribution companies, British Airports Authority, and Cable and Wireless.

(c) RAND 1999 
The documentary record. Nothing we read contradicted our characterization of state-owned firms as organizations in which continued management tenure in the same position was not contingent on financial performance. In brief summary, the record suggests the presence of public interest and political goals in state-owned firms in addition to financial goals, but it also suggests that continued tenure was not particularly contingent on satisfying any of these goals. Rather, the evidence indicates a lack of clarity of goals in state-owned firms and a lack of effort to align rewards and penalties for managers with these goals.

Reflecting the presence of noncommercial objectives in state-owned enterprises, the U.K. government reported, in a White Paper on performance evaluation in stateowned enterprises, that "significant costs and benefits can occur which are outside the financial concern of the industry and it is the special responsibility of the Government to ensure that these 'social' factors are reflected in the industries planning" (HM Treasury, 1967). Illustrative of the manipulation of firms toward political objectives, politicians fearful of electoral costs of increased unemployment slowed down restructuring in the steel and coal industries, forced managers in the Central Electricity Generating Board to rely on more expensive British coal and British-manufactured plants, and instructed British Airways management to use British-made planes instead of Boeing, their preferred choice.

The presence of the multiple objectives and multiple masters did not simply lead to accountability systems tied to a wider set of goals, but instead, reportedly, lowered overall accountability in the system. Government White Papers (1961, 1967, and 1978) continually recognized weaknesses in the system. One of the principal criticisms of "arm's-length" control in state-owned firms, highlighted in the 1961 report, was a lack of clarity of owners' objectives. The report (HM Treasury, 1961) characterizes the standard policy direction as demanding that "revenues should on an average of good and bad years (or some similar phrase) be not less than sufficient to meet all items properly chargeable to revenue." Managers and boards were left to decide on the appropriate tradeoffs between commercial and noncommercial objectives.

Summarizing the system, the National Economic Development Office (1976) reported that

there is in practice considerable ambiguity about the accountability of boards of nationalised industries-to whom they are responsible, for what functions and dimensions of performance, and over what time scale. Ministerial responsibility is correspondingly ill-defined. The resulting confusion leads to a situation in which boards are not effectively required to account for their performance in a systematic or objective mannerwhether it be to Parliament, to Ministers, to other legitimate interest groups or to the wider public. Also Ministers are not generally held responsible for the consequences of their interventions (pp. 38-39).

Supporting this characterization, there was scant evidence that boards attempted to align management's interests to any government goals through dismissal policies. As the National Economic Development Office (1976) reported,

it is widely acknowledged in both departments and corporations that the power of appointment and reappointment is sometimes used by the government as an inducement to individual board members when the government is seeking to implement its policies ... . However, the incidence of cases where Chairmen have not been reappointed seems to depend as much on the incompatibility of the key personalities as on disagreements over particular policy issues. There is little publicly available evidence that reappointment is linked to a chairman's or a corporation's performance (p. 35).

Reflecting the condemnation of corporate governance measures, the U.K. government totally reformed its accountability system in state-owned firms along the lines 
laid out in the 1978 White Paper. ${ }^{26}$ Accountability was enhanced by publishing both targets and performance relative to past targets in annual reports. Additionally, starting in 1981, the government announced an intention to close the gap between salaries of private and public sector managers, in some cases experimenting with performancerelated pay. ${ }^{27}$ These governance changes reportedly tightened managerial control after 1979, and as our data show, performance clearly improved in state-owned firms in the 1980s. Nonetheless, these reforms did not eliminate suspicions of agency problems in state-owned firms.

Executive testimony. The most suggestive evidence of both a relative lack of accountability in state-owned firms (rather than attention to other goals) and of significant increases in accountability following privatization came from our interviews. Present and former managers reported how privatization had transformed their jobs and owners' expectations.

Focusing on the time between announcement and privatization, managers reported few direct actions by government but an increase in attention placed on manager's skills and financial acumen. Like the role played by Lord King at British Airways, there were a few high-profile cases of top managers being chosen by government officials to prepare firms for privatization. Less well known is the government's systematic effort to evaluate management skills. For example, in the electric distribution and water supply companies, the government assembled a team of merchant bankers who, with the minister responsible for the nationalized firm, performed a discrete review of chairman and deputy chairman in companies being prepared for privatization. In a few instances, as our data reflect, managers were replaced in advance of privatization, but by and large top managers were left in their positions. Once the minister gave approval for the chairman and deputy chairman, the chairman had latitude to select candidates for other board positions (both executive and nonexecutive). The minister concurred in almost all such appointments. This description is consistent with our empirical finding of a relatively low level of turnover in the buildup to privatization and in the shift (albeit insignificant) toward more performance accountability.

Following privatization, executives reported significant increases in the intensity of scrutiny. Leading the scrutiny were financial analysts who generated reports on all privatized companies, devoting significant attention to the quality of different management teams. These reports, the most influential of which came from utility groups in 12-15 main merchant banks, were circulated to existing and prospective shareholders as well as to board members of privatized firms. Through this channel, the executives we interviewed reported that owners began to play a greater role in setting corporate objectives. In all cases, managers reported that financial analysts, including analysts of large institutional shareholders, were considerably more active and effective in projecting firm cash flow under various assumptions than were government officials. For example, market analysts impose similar projections for retail sales in British Airports Authority (BAA) as they introduce for other retailers. Market analysts also benchmark the firm against international comparison firms. As a result of these analyses, firm management believed they had to define objectives within the range of private-sector

${ }^{26}$ The most important feature of the new system was the identification of three easily monitored targets: financing limits, financial return measured by rate of return on net assets, and efficiency measured by unit cost of operation.

${ }^{27}$ See Review Body on Top Salaries (1981) for the policy statement. Cragg and Dyck (1998b) provide empirical evidence of increases in pay, but that the gap actually grew over this time period.

() RAND 1999 
forecasters with an unambiguous increase in expected financial performance relative to the period of state ownership.

The following comment from a high-level executive shows the perceived change in power from management to analysts and institutional investors:

Officially (under state ownership) the Treasury set performance targets for financial returns and productivity. In reality the Treasury was bamboozled. We had all of the information and we determined our own targets. That has all changed with privatization. Now financial analysts are poring over our analyses. They send weekly and monthly updates to us and to our non-executive directors. We have to propose financial targets in line with analysts' expectations. More importantly, the market holds us to account. We fail to hit that number and the stock market price takes a hit. Don't think that our shareholders aren't aware.

The scrutiny made a difference. While executives were hard pressed to indicate instances in which top managers were fired for poor financial performance prior to privatization (a number in fact noted an example where a manager in a state-owned firm was fired for the exact opposite reason of having pushed too hard for financial improvements and having annoyed powerful union interests), all could identify multiple examples of forced departures after privatization. One manager highlighted specifically the link between the firm's share price and his job prospects: "The primary reason we focus on the market is our personal reputation. The minute we lose shareholder support our personal survival is on the line. The threat of firing is an extraordinarily strong motivation."

The managers we interviewed suggested that looking at one level below the top executives would in fact reveal more significant changes in management personnel and accountability. All executives recounted how they had actively brought in new managers to the top team around the privatization event, often actively seeking outsiders to meet new demands. The individuals sought most actively were those with a financial background who could discuss firm performance with financial analysts, and individuals with experience in sales and marketing. Our findings of significantly higher firing in privatized than in state-owned firms at the top management level but not at the top executive level is consistent with this description.

\section{Conclusions}

- Our principal finding is that privatization is associated with an increased sensitivity of resignations and fires to changes in financial performance. In firms with at least four years in the private sector, managers were more likely to resign when the firms performed poorly. Ex ante knowledge of this relationship serves as an incentive device. This apparent relationship between continued tenure and financial performance mimics the experience of executives of publicly traded firms. It contrasts with that of executives in state-owned enterprises, where we found no evidence of turnover sensitivity related to performance in the period before the government announced its intention to privatize. Contrary to simple agency theory and the expectations of many analysts and executives in privatized firms, private owners began to introduce systems that aligned managers' incentives with owners' financial interests. The market for corporate control appears to function in replacing managers and, eventually, in disciplining poor managerial performance. Qualitative evidence supports this characterization as an increase in accountability rather than a change from political to financial objectives.

The privatization event itself appears unique. There is greater government attention to financial performance in the buildup to privatization. There is also no apparent relationship between turnover and financial performance using accounting returns in the early years of privatization.

Our analysis of management replacement surrounding and following privatization in the United Kingdom echoes the results from eastern Germany, Russia, and Mexico 
and suggests that the replacement of human capital is an important part of the privatization process. Apparently, private owners think that it is not sufficient to change incentives but that personnel also need to be replaced. The scramble to hire top executives with strong financial and marketing credentials around privatization suggests that executives in state-owned firms lacked a number of the skills necessary to manage a large publicly traded corporation.

These findings of no turnover sensitivity to financial performance under state ownership, and of a heightened level of management replacement and more sensitivity to changes in financial performance in privatized firms, brings into question the need for special attention to governance in privatized firms. This result also brings into question privatization efforts that reduce the ability to replace managers. More work needs to be done to see if the same incentive changes are found for managerial compensation, if the speed of introduction of changes is linked to restrictions on corporate governance activity, and if ownership changes also lead to incentive changes in countries with weak markets for corporate control and less-efficient capital markets.

\section{Appendix}

- To collect information for state-owned enterprises, we contacted the public relations officer of the stateowned entity or the large private entity that once was a nationalized firm. Following an initial letter contact, followed by fax and phone messages, we asked for copies of annual reports from 1970 to the present. For firms that were unwilling or unable to provide information, we used other channels including archived copies from Harvard University's Baker Library, the libraries of the Department of Trade and Industry, the Treasury, the Office of Water Services (OFWAT), and the Electricity Association. Some of the differences in the starting years for our sample of state-owned firms is attributable to the difficulty of assembling data from these varied sources. Other differences are attributable to the date at which firms became organized as state-owned enterprises. For example, the water companies only took their current form in 1973.

We used company annual reports as the primary source for our information on management and firm performance. For state-owned firms, we relied on annual reports for all information. For management information for publicly-traded firms, we consulted archived annual reports (1970-1980) and copies of annual reports from microfiche and CD-ROM (1981-1995). We used the Datastream electronic database for performance information for the publicly traded and privatized firms in our sample as well as for the performance of other firms in the same industry classification. We excluded the actual year of privatization (final year of state ownership) from the tables and all of our regression results because of accounting changes coinciding with privatization and the difficulty of accurately identifying who made board decisions during this year. We always took note of the date of the fiscal year end, which was in almost all cases March 31 or December 31. We define the data from a company with a March 31 fiscal year end as the data for the previous fiscal year (e.g., data from an annual report dated March 31, 1984, is classified as data from 1983).

To accurately classify management resignations, we recorded the month that each manager assumed their position and the month they left the firm. Using biographical information from Who's Who, we were able to identify starting dates even for managers who joined our dataset in the middle of a spell. We identified a manager as having resigned in a particular reporting year if the manager occupied a top management position for less than six months in the reporting year. To avoid double counting of management changes, we did not record a management resignation if the titles of individuals in the top management team were shuffled but there was no change in team composition.

The accounting convention used for reported earnings is historical cost accounting. For the financial data we collected, whenever there was a change in accounting conventions we used restated financial accounts so that changes from one year to the next were not driven by changes in accounting rules. For the few instances when it was impossible to assemble such a series, we dropped the transition years. For a number of the state-owned firms, the government also required the firm to produce a set of accounts based on the current-cost convention. This requirement was introduced in 1980, and some regulated firms are still required to present current-cost accounting numbers.

We used historical cost accounting because it was possible to assemble a complete data series for both privatized and publicly traded firms using this convention. Moreover, historical cost accounting is the preferred convention, used by all publicly traded firms and by firms following privatization. The Norweb annual report (1991) defines the difference as the following: "This basis of accounting [current cost] is an attempt to recognize in financial statements the effect of inflation on a business. It requires that fixed assets and stock should be shown in the balance sheet at their replacement cost. This in turn has the effect that a higher 
depreciation charge is made in the profit and loss acount and the cost of sales is increased." Moreover, in an earlier version of this article, in which we used current-cost accounting numbers, our results were reinforced with higher coefficient estimates and levels of statistical significance for privatized firms.

We constructed industry-comparable information at the lowest possible level using information available from Datastream. Datastream provides industry classification using the Financial Times system. This system identified industries at a level comparable to somewhere between a two- and three-digit standard industrial code (SIC). For all firms, we collected comparable performance information for all firms in the Datastream database with the same Financial Times identifier, and we dropped the sample company from the resulting group of firms. For a few companies, the number of firms in that industry classification was two or less. Rather than using this limited or nonexistent group of sample companies, we elected as a second-best solution to widen our definition of an industry group.

The wider industry group was the next-highest level of aggregation available using the Financial Times industry classification. Again, we dropped the sample company from the group of companies in constructing industry performance. For companies such as British Airways prior to the 1990s, this involved defining a transport group that included all firms with the identifier railways, airlines, coach lines, other shipping, and other transport. For some utilities such as British Telecom prior to the creation of other telecom firms, this involved constructing a broad utilities classification including all firms with classifiers of electric, water, gas distribution, telecoms, national coal board, and the post office. Other broad categories used included consumer goods for BAT Industries and mining and extractive industries for companies such as British Gas.

\section{References}

Alchian, A.A. Economic Forces at Work. Indianapolis: Liberty Press, 1977.

Barbe, A., Butler, W., Messier, J., Rolland, Y., And VieIllard, P., eds., Denationalisations: Les Leçons de l'Etranger. Paris: Economica, 1986.

TABLE A1 Descriptive Statistics of Variables Using Full Sample

\begin{tabular}{|c|c|c|c|c|c|}
\hline & $\begin{array}{l}\text { Number of } \\
\text { Observations }\end{array}$ & Mean & $\begin{array}{l}\text { Standard } \\
\text { Deviation }\end{array}$ & Minimum & Maximum \\
\hline \multicolumn{6}{|l|}{ All firms } \\
\hline Age & 2,598 & 56.5 & 6.8 & 27 & 92 \\
\hline Tenure & 2,705 & 4.9 & 4.3 & 0 & 34 \\
\hline After-tax return on net operating assets & 2,855 & .067 & .073 & -.87 & .30 \\
\hline Change in after-tax RONOA & 2,650 & .002 & .056 & -.83 & .88 \\
\hline \multicolumn{6}{|l|}{ State owned } \\
\hline Age & 945 & 56.4 & 5.8 & 35 & 71 \\
\hline Tenure & 979 & 3.9 & 2.8 & 1 & 21 \\
\hline After-tax return on net operating assets & 1,015 & .036 & .096 & -.87 & .23 \\
\hline Change in after-tax RONOA & 854 & .005 & .091 & -.83 & .88 \\
\hline \multicolumn{6}{|l|}{ Privatized } \\
\hline Age & 402 & 56.4 & 6.7 & 42 & 74 \\
\hline Tenure & 402 & 4.8 & 3.3 & 0 & 14 \\
\hline After-tax return on net operating assets & 411 & .097 & .050 & -.06 & .22 \\
\hline Change in after-tax RONOA & 408 & .003 & .028 & -.13 & .13 \\
\hline \multicolumn{6}{|l|}{ Publicly traded } \\
\hline Age & 1,251 & 56.6 & 7.5 & 27 & 92 \\
\hline Tenure & 1,324 & 5.7 & 5.1 & 0 & 34 \\
\hline After-tax return on net operating assets & 1,429 & .081 & .046 & -.12 & .30 \\
\hline Change in after-tax RONOA & 1,388 & .000 & .026 & -.14 & .19 \\
\hline
\end{tabular}

Note: The sample has 3,139 observations. Omission of outliers further reduced the sample to 3,039 observations. Missing data leads to a further decrease in the number of reported observations.

(C) RAND 1999. 
Barberis, N., Boycko, M., Shleifer, A., And Tsukanova, N. "How Does Privatization Work? Evidence from the Russian Shops." Journal of Political Economy, Vol. 104 (1996), pp. 764-790.

Bishop, M. And KaY, J. "Does Privatization Work? Lessons from the UK.” London Business School, Centre for Business Strategy Report Series, 1988.

Botrdman, A.E. AND Vining, A.R. "Ownership and Performance in Competitive Environments: A Comparison of the Performance of Private, Mixed, and State-Owned Enterprises." Journal of Law and Economics, Vol. 32 (1989), pp. 1-33.

Boycko, M., Shleifer, A., And Vishny, R.W. "A Theory of Privatisation.” Economic Journal, Vol. 106 (1996), pp. 309-319.

Chamberlain, G. "Panel Data." In Z. Griliches and M. Intriligator, eds., Handbook of Econometrics, Vol. 2. New York: North-Holland, 1984.

Cosh, A. "The Remuneration of Chief Executives in the United Kingdom." Economic Journal, Vol. 85 (1975), pp. 75-94.

CRagG, M.I. And Dyck, I.J.A. "Management Control and Privatization in the United Kingdom: A Quiet Life Disturbed." Harvard Business School Working paper no. 97-045, 1998a.

AND — . "Privatization, Compensation and Management Incentives: Evidence from the United Kingdom." Harvard Business School Working Paper no. 99-075, 1998b.

De Alessi, L. "Managerial Tenure Under Private and Government Ownership in the Electric Power Industry." Journal of Political Economy, Vol. 82 (1974), pp. 645-653.

Denis, D.J. AND DenIS, D.K. "Performance Changes Following Top Management Dismissals." Journal of Finance, Vol. 50 (1995), pp. 1029-1057.

Demsetz, H. Ownership, Control and the Firm: The Organization of Economic Activity, Vol. 1. New York: Basil Blackwell, 1988.

Dyck, I.J.A. "Privatization in Eastern Germany: Management Selection and Economic Transition." American Economic Review, Vol. 87 (1997), pp. 565-597.

Fraser, R.D. And Wilson, M. Privatization: The UK Experience and International Trends. London: Longman, 1988.

Galal, A., Jones, L., Tandon, P., And Vogelsang, I. Welfare Consequences of Selling Public Enterprises. New York: Oxford University Press, 1994.

GEDDES, R.R. "Ownership, Regulation, and Managerial Monitoring in the Electric Utility Industry." Journal of Law and Economics, Vol. 40 (1997), pp. 261-288.

GregG, P., Machin, S., And Szymanski, S. "The Disappearing Relationship Between Directors' Pay and Corporate Performance." British Journal of Industrial Relations, Vol. 31 (1993), pp. 1-10.

Heath, J. "Financial and Economic Control." In A Study of UK Nationalised Industries. London: HM Stationery Office, 1976.

Hicks, J.R. "Annual Survey of Economic Theory: The Theory of Monopoly.” Econometrica, Vol. 3 (1935), pp. $1-20$.

House OF Commons. “First Report of the Select Committee on Nationalised Industries 1967-1968.” London: HM Stationery Office, 1968.

—. "Report of the Select Committee on Nationalised Industries 1978-1979." Sub Committee E. London: HM Stationery Office, 1979.

HM TREasury. Financial and Economic Obligations of the Nationalised Industries. Cmnd. 1337. London: HM Stationery Office, 1961.

- Nationalised Industries: A Review of Economic and Financial Objectives. Cmnd. 3437. London: HM Stationery Office, 1967.

—. The Nationalised Industries. Cmnd. 7131, London: HM Stationery Office, 1978. . Her Majesty's Treasury Guide to the UK Privatisation Programme. London: HM Stationery Office, 1995.

Kang, J.-K. And Shivdasani, A. "Firm Performance, Corporate Governance, and Top Executive Turnover in Japan." Journal of Financial Economics, Vol. 38 (1995), pp. 29-58.

Kaplan, S.N. "Top Executives, Turnover, and Firm Performance in Germany." Journal of Law, Economics and Organization, Vol. 10 (1994), pp. 142-159.

LAfFont, J.-J. AND TiRole, J. "Privatization and Incentives." Journal of Law, Economics and Organization, Vol. 7 (1991), pp. 84-105.

LaPorta, R. ANd Lopez-De-Silanes, F. "The Benefits of Privatization: Evidence from Mexico." NBER Working Paper no. 6215, 1997.

LoPEZ-DE-SiLANES, F. "Determinants of Privatization Prices." Quarterly Journal of Economics. Vol. 112 (1997), pp. 965-1025.

Megginson, W.L., Nash, R.C., And van Randenborgh, M. "The Financial and Operating Performance of Newly Privatized Firms: An International Empirical Analysis.” Journal of Finance, Vol. 49 (1994), pp. 403-452.

(C) RAND 1999 
National Economic Development Office. A Study of U.K. Nationalised Industries. London: HM Stationery Office, 1976.

PERCY, J.P. "The Cadbury Report and Corporate Governance in the UK." CPA Journal, Vol. 65 (1994), pp. $24-28$.

Review Body on Top SAlaries. Report No. 6. Cmnd. 5846, 1974.

- Report No. 10. Cmnd. 7253, 1978.

. Report No. 14. Cmnd. 7952, 1980.

Report No. 15. 1981.

SaPpington, D.E.M. And Stiglitz, J.E. "Privatization, Information, and Incentives." Journal of Policy Analysis and Management, Vol. 6 (1987), pp. 567-582.

ShapIRo, C. AND Willig, R.D. "Economic Rationales for the Scope of Privatization." In E.E. Bailey and J.R. Pack, eds., The Political Economy of Privatization and Deregulation. Aldershot, U.K.: Elgar, 1995.

Shleifer, A. AND Vishny, R.W. “A Survey of Corporate Governance.” Journal of Finance, Vol. 52 (1997), pp. 737-783.

Vickers, J. And Yarrow, G. Privatization: An Economic Analysis. Cambridge, Mass.: MIT Press, 1988.

WARnER, J.B., WatTs, R.L., AND WrUCK, K.N. "Stock Prices and Top Management Changes." Journal of Financial Economics, Vol. 20 (1988), pp. 461-492.

Weisbach, M.S. “Outside Directors and CEO Turnover.” Journal of Financial Economics, Vol. 20 (1988), pp. 431-460.

Who's Who. London: A \& C Black, various years.

Wolfram, C.D. "Increases in Executive Pay Following Privatization." Journal of Economics and Management Strategy, Vol. 7 (1998), pp. 327-361.

YARrow, G. "Privatization and Economic Performance in Britain." Carnegie-Rochester Conference Series on Public Policy, Vol. 31 (1989), pp. 303-344. 